\title{
Studies on the Interactions of Thyroid Hormone and Catecholamines *
}

\author{
George A. Bray $\dagger$ \\ (From the National Institute for Medical Research, Mill Hill, London, England)
}

Since the original demonstration by MagnusLevy (1) of the rise in respiratory exchange after feeding thyroid and the synthesis of thyroxine by Harington and Barger (2), the physiological effects of insufficient and of excess amounts of thyroid hormone have been well described (3). The cellular and biochemical mechanism by which thyroid hormones produce these effects is, however, still far from clear. Numerous studies have shown a direct effect of thyroxine on various in vitro systems (4), but these effects are often difficult to relate to the physiological effects of thyroid hormone.

The resemblance of the symptoms of hyperthyroidism to the effects of sympathomimetic amines has given rise to the concept that the primary effect of thyroxine may be to alter the tissue sensitivity to epinephrine and norepinephrine. Substantial evidence, both clinical and experimental, has accumulated to support the idea that sensitivity to catecholamines varies directly with the intensity of action of thyroid hormone (5-16).

Evidence for the converse hypothesis, i.e., that the tissue response to thyroxine is mediated by the action of catecholamines, is difficult to interpret. It is relatively easy to alter the state of thyroid activity and then test the response to catecholamines. It is far more difficult to remove completely sources of catecholamines before testing the effect of thyroxine. Although many studies (17-23) have shown an inhibition of the response to thyroxine after removing or inhibiting catecholamines, most of these studies have failed to exclude completely the presence of catecholamines. Other studies (24-28) have failed to show any change in the effect of thyrox-

* Submitted for publication June 7, 1963; accepted October 10, 1963.

$\dagger$ Postdoctoral fellow of the National Science Foundation.

Present address: Department of Medicine, Pratt Clinic-New England Center Hospital, Boston, Mass. ine when catecholamines have been blocked by various pharmacological agents. Consequently the question of whether thyroxine acts only through its effects on catecholamines remains unsettled.

In an effort to shed further light on this problem, studies using a combination of surgical and pharmacological techniques have been carried out. The effect of thyroid hormones and reserpine independently and in combination on thyroidectomized or thyroidectomized and adrenodemedullated rats has been investigated using metabolic rate, heart rate, and growth as indicators of response.

\section{Methods}

Male rates of the hooded or albino strains from the Mill Hill breeding stock were used for thyroidectomy and adrenodemedullation, which was performed under ether anesthesia. Thyroidectomy was done through a mid-line incision (29), and to destroy any remaining thyroid tissue, 25 to $50 \mu \mathrm{c}$ of $\mathrm{I}^{181}$ was given 1 week after the operation. Adrenodemedullation, performed through bilateral flank incision at the same time as thyroidectomy, was done by mobilizing the adrenals and incising the capsule. The medulla and cortex were then removed from the capsule by gentle pressure on each side of the adrenal. Tap water was given postoperatively, since in our experience drinking water containing $0.9 \%$ sodium chloride did not alter survival. Animals were not used until at least 6 weeks after operation, at which time the hooded rats weighed $148 \mathrm{~g}$ and the albino rats $187 \mathrm{~g}$, on the average. At the end of the studies on adrenodemedullated animals the adrenals were removed, homogenized in $10 \mathrm{ml}$ of cold $5 \%$ trichloroacetic acid, and centrifuged. The supernatant fluid was assayed for epinephrine by a modification of the method of Crout (30). With one exception, the epinephrine content was less than $1 \%$ of that in the adrenals from normal control animals.

Atropine, epinephrine, and reserpine were obtained from the British Drug Houses. 1 Atropine, 35 or $70 \mathrm{mg}$ per $100 \mathrm{~g}$, was given subcutaneously as a $10 \%$ solution in $0.15 \mathrm{M}$ sodium chloride, a dose that is sufficient to produce cholinergic blockade in the rat (29). Epinephrine was given subcutaneously at a dose of $20 \mu \mathrm{g}$

1 London, England. 
per $100 \mathrm{~g}$ as described in individual experiments. Reserpine in doses of $10 \mu \mathrm{g}$ per rat or $50 \mu \mathrm{g}$ per rat was given intramuscularly as a suspension in peanut oil. Guanethidine ${ }^{2}$ at a dose of $0.5 \mathrm{mg}$ per $100 \mathrm{~g}$ was given subcutaneously once daily. Triiodothyronine, $10 \mu \mathrm{g}$ per rat, was given in $0.2 \mathrm{ml}$ of alkaline saline. For the growth studies $8 \mu \mathrm{g}$ of thyroxine in alkaline saline or 25 $\mu \mathrm{g}$ of reserpine in peanut oil, or both, were administered twice weekly. Control animals were given injections of peanut oil, alkaline saline, or both.

Oxygen consumption was measured on individual rats by a modification of the closed-circuit technique described by Maclagan and Sheahan (31). Rats were placed in Kilner jars of approximately 3-L size, containing soda lime and anhydrous calcium chloride. The rats were equilibrated in a 22 to $23^{\circ} \mathrm{C}$ room for 10 to 20 minutes after which six 3-minute readings of oxygen consumption were taken. These readings were averaged to give the pressure change per unit time and were expressed as milliliters of oxygen per gram per hour.

The oxygen consumption of tissue slices was measured by the Warburg manometric method. Tissue slices of heart and liver prepared by the Deutsch method (32) were incubated in Krebs-Ringer phosphate with $100 \mathrm{mg}$ per $100 \mathrm{ml}$ glucose.

The heart rate was measured under light ether anesthesia by a rate meter that recorded rates between 210 and 510 beats per minute. The end point was taken as the plateau that occurred just before the rat awakened.

2 Guanethidine (Ismelin ampules) was kindly supplied by Ciba Laboratories, London, England.

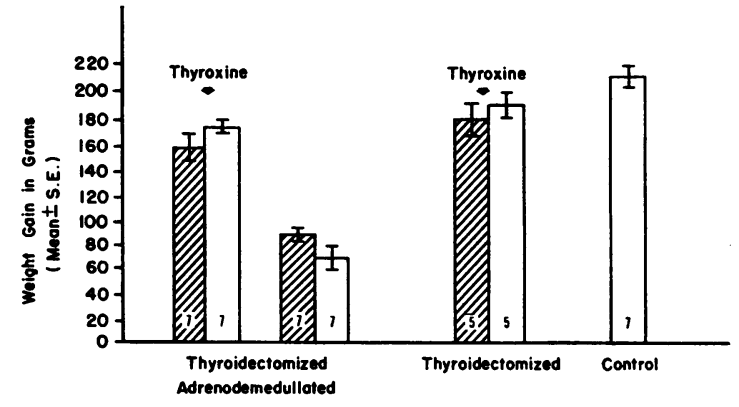

Fig. 1. EFFECT OF THYROXINE AND RESERPINE ON THE GROWTH OF THYROIDECTOMIZED, THYROIDECTOMIZED-ADRENODEMEDULLATED, AND CONTROL RATS. The weight gain over the 10 weeks of the experiment is shown on the ordinate. The number in each bar is the number of rats. Animals represented by the shaded bars received reserpine. Thyroxine was given to four groups as labeled.

\section{Results}

I. Growth rate. The growth rate was measured in two experiments, one on albino and the other on hooded rats. Weanling rats were operated upon and given $25 \mu \mathrm{c}$ of $\mathrm{I}^{131}$, and the experiment was begun 1 week later. The results of an experiment on 45 rats are summarized in Figure 1 . On the ordinate is shown the difference between the initial and final weight for each group. The first 4 bars from left to right each represent the seven thyroidectomized-adrenode-

TABLE I

Effect of triiodothyronine and reserpine on the heart rate and BMR of thyroidectomized or thyroidectomized-adrenodemedullated male albino rats

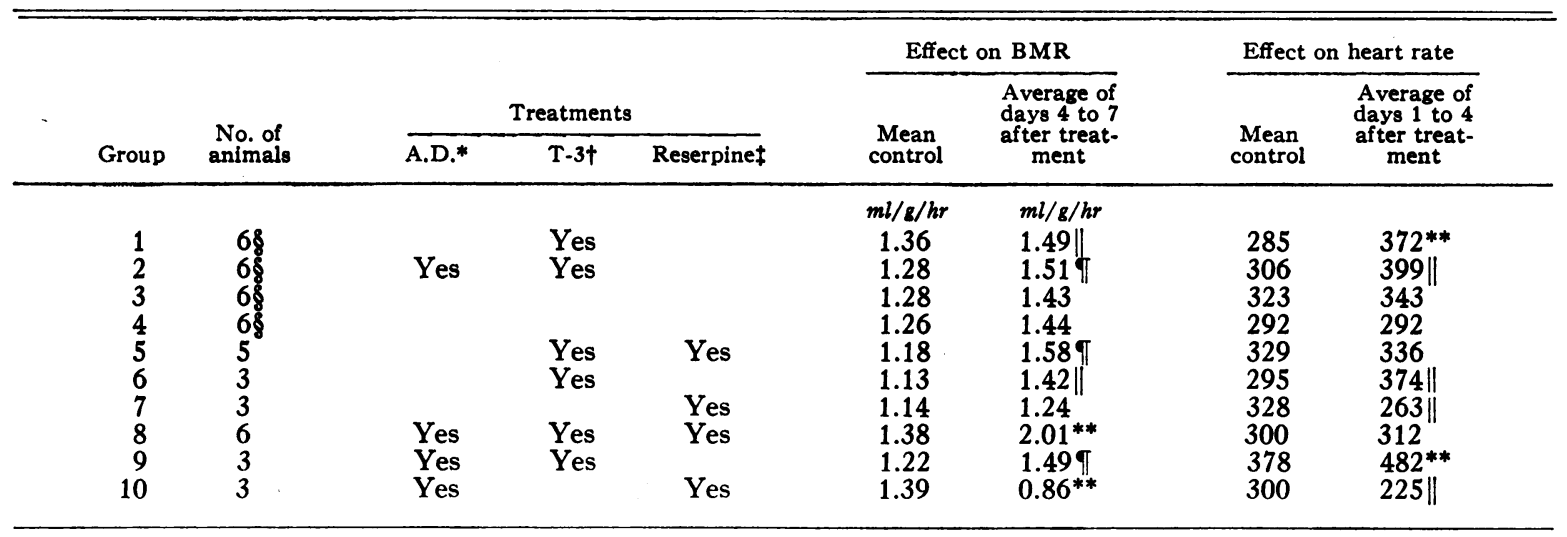

* A.D., adrenodemedullation.

$\dagger \mathrm{T}-3$, triiodothyronine, $10 \mu \mathrm{g}$ per rat every other day for 1 week and then daily for a second week.

\$ 50 ug per rat per day for 3 days, then on alternate days.

$\$$ Heart rates obtained on only half of each group.

II $p<0.05$.

If $\mathrm{p}<0.01$.

${ }_{* *} \mathrm{p}<0.001$. 
medullated rats, bars 5 and 6 represent two groups of five thyroidectomized rats each, and bar 7 is the control group. The thyroxine-treated groups (bars $1,2,5$, and 6 ) received $8 \mu \mathrm{g}$ of thyroxine twice weekly. The animals represented by crosshatched bars each received $25 \mu \mathrm{g}$ of reserpine twice weekly. Controls received appropriate vehicle. The thyroidectomized animals treated with thyroxine and peanut oil showed a smaller weight gain than the normal rats, but this difference was not statistically significant. The combination of thyroidectomy and adrenodemedullation resulted in a highly significant reduction in weight gain when compared with normal rats. An analysis of variance within the group of 28 thyroidectomized-adrenodemedullated rats (bars 1 to 4 in Figure 1) showed a highly significant effect of thyroxine on growth, no effect of reserpine, and a statistical covariance between the effects of thyroxine and reserpine that was significant at the $p=0.05$ level. This occurred because in the rats receiving thyroxine, reserpine slowed growth slightly while the rats receiving no thyroxine grew somewhat more when given reserpine.

In experiment 2 , a similar study was made on 30 hooded rats. In this experiment 24 thyroidectomized-adrenodemedullated animals were divided into four groups with six rats serving as normal controls. Half of the experimental rats received $8 \mu \mathrm{g}$ of thyroxine twice weekly. Six thyroxinetreated and six vehicle-treated rats received 25 $\mu \mathrm{g}$ of reserpine. The remaining groups including normal controls received peanut oil. The hooded rats grew more slowly than the albino rats and showed a smaller response to thyroxine. There was no detectable effect of reserpine.

II. Metabolic rate and heart rate. Two experiments were performed to study the effect of triiodothyronine and reserpine on the oxygen consumption and heart rate of thyroidectomized and thyroidectomized-adrenodemedullated rats. The first experiment on 24 thyroidectomized and 23 thyroidectomized-adrenodemedullated rats is summarized in Table I and Figures 2, 3, and 4 . Twelve thyroidectomized and twelve thyroidectomized-adrenodemedullated rats were used to test the effect of adrenodemedullation on heart rate and oxygen consumption. Six rats from each group were given $10 \mu \mathrm{g}$ of triiodothyronine every other day, and the control animals were given an
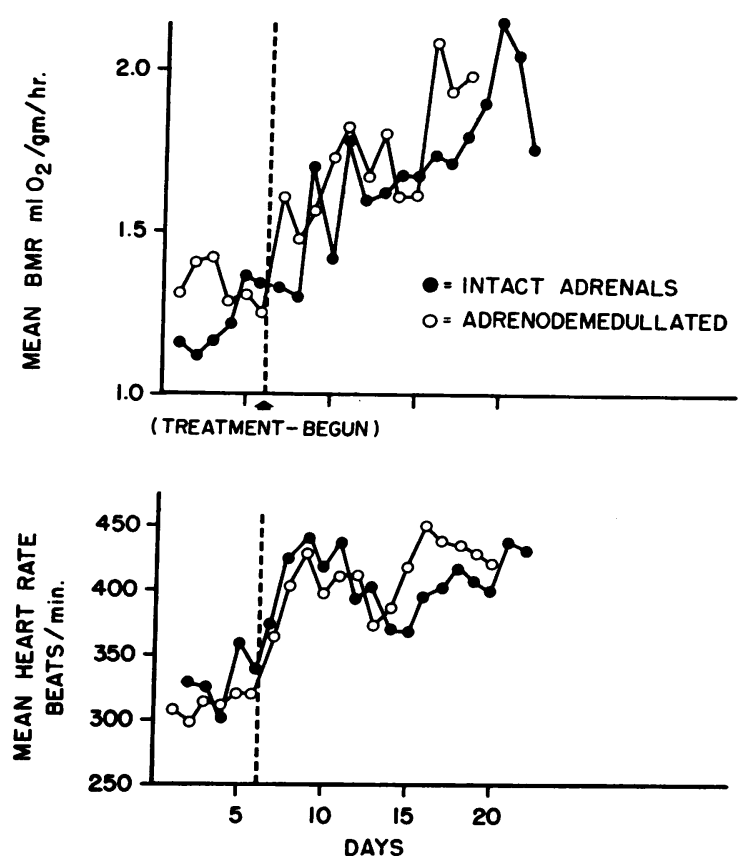

Fig. 2. EFFECT OF TRIIODOTHYRONINE ON THE HEART RATE AND METABOLIC RATE OF THYROIDECTOMIZED AND THYROIDECTOMIZED-ADRENODEMEDULLATED RATS. The metabolic rate in milliliters of oxygen per gram of body weight per hour is shown in the upper frame and heart rate in the lower frame. Each point represents the average of readings from three animals.

equal volume of alkaline saline. Adrenodemedullation did not alter the mean control values for heart rate and BMR of thyroidectomized rats, nor did it influence the prompt and significant rise in heart rate and BMR after triiodothyronine (Table I, groups 1 to 4 ). The remaining twelve rats from each group operated on were used to test the effect of reserpine on the rise in heart rate and BMR after triiodothyronine. Six rats from each surgically prepared group received 10 $\mu \mathrm{g}$ of triiodothyronine on alternate days for 1 week and then daily for a second week and $50 \mu \mathrm{g}$ of reserpine daily for 3 days and then on alternate days throughout the remainder of the experiment. (Only two $50-\mu \mathrm{g}$ injections of reserpine were given to the thyroidectomized-adrenodemedullated rats, Table I, group 10). As Figure 2 shows, (Table II, groups 6 and 9), the response of the heart rate to triiodothyronine was rapid and not influenced by removal of the adrenal medulla. The rise in metabolic rate after triiodothyronine occurred somewhat more slowly than the rise in 
heart rate, but was significantly different from control values within 4 days. The data in Figure 3 (Table I, groups 5 and 8 ) show that the tachycardia induced by triiodothyronine was prevented by reserpine, but that the rise in metabolic rate was not. The rise in BMR after triiodothyronine occurred more rapidly and was greater in the reserpine-treated rats.

The difference between the response of thyroidectomized and thyroidectomized-adrenodemedullated rats to reserpine alone is shown in Figure 4 (Table I, groups 7 and 10). The thyroidectomized-adrenodemedullated rats showed a steady and progressive drop in both heart rate and metabolic rate with the drop in heart rate preceding the fall in BMR. The rats became inactive, and they were all dead within 1 week after initiation of reserpine, yet the animals lost no more than $10 \%$ of their body weight. Conversely, none of the thyroidectomized' animals with intact adrenal
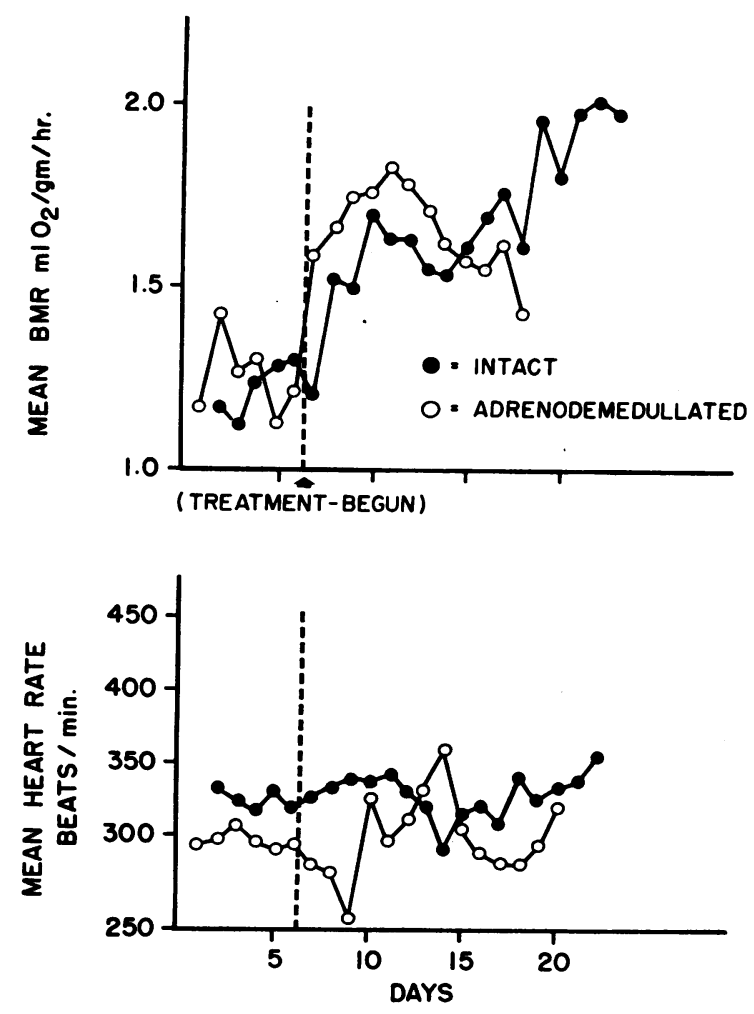

FIG. 3. EFFECT OF TRIIODOTHYRONINE AND RESERPINE ON THE HEART RATE AND METABOLIC RATE OF THYROIDECTOMIZED AND THYROIDECTOMIZED-ADRENODEMEDULLATED RATS. Each point represents the average of readings from five or six animals.

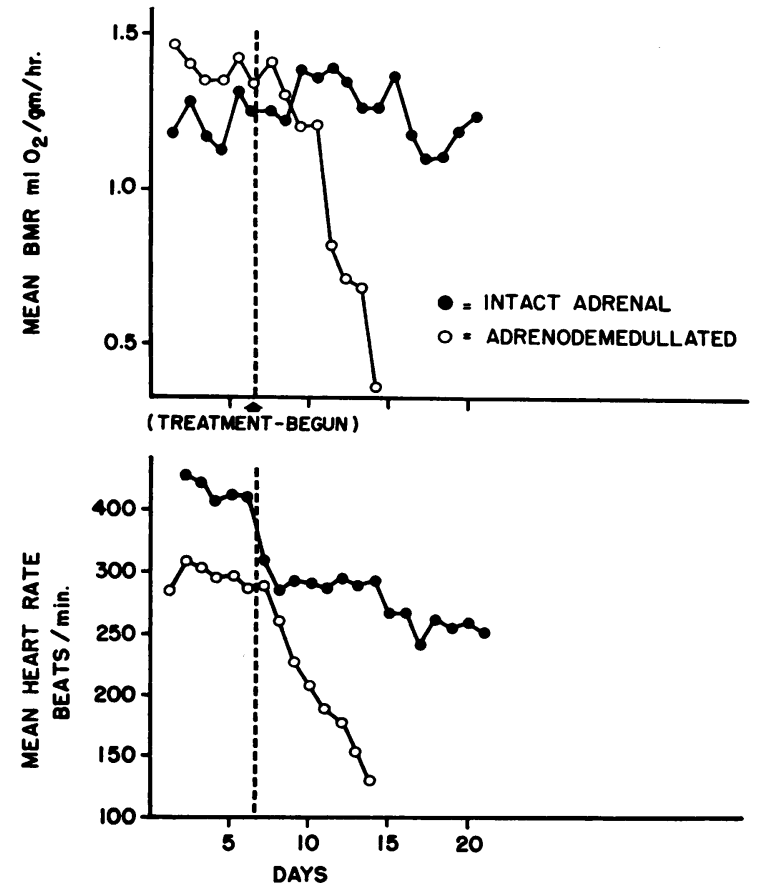

Fig. 4. EFFECT OF RESERPINE ON THE HEART RATE AND METABOLIC RATE OF THYROIDECTOMIZED AND THYROIDECTOMIZED-ADRENODEMEDULLATED RATS. Each point represents the average of readings from three animals.

medullas showed a decrease in metabolic rate, and none died when given reserpine. They did, however, show a significant reduction in heart rate that was not progressive. The animals remained active throughout the study. To determine whether the effect of removing the adrenal medulla was solely due to epinephrine, three rats were given $50 \mu \mathrm{g}$ of reserpine daily for 3 days and then on alternate days along with $20 \mu \mathrm{g}$ per $100 \mathrm{~g}$ of epinephrine twice daily when reserpine was given and once daily when no reserpine was given. The result of the experiment is presented in Table II along with the data for group 10 from Table I. Epinephrine, like triiodothyronine (Figure 3), prevented the decline in the heart rate and pre-

TABLE II

Effect of epinephrine on the heart rate of thyroidectomizedadrenodemedullated rats treated with reserpine

\begin{tabular}{lcc}
\hline \hline & \multicolumn{2}{c}{ Mean heart rate } \\
\cline { 2 - 3 } & Control & Days 5 to 7 \\
\hline Epinephrine & 281 & 290 \\
No epinephrine & 300 & 179
\end{tabular}


vented the death of the thyroidectomized-adrenodemedullated rats treated with reserpine.

Additional data on the changes in heart rate produced by reserpine were obtained to define the effect more clearly. Reserpine, $50 \mu \mathrm{g}$, was given to six thyroidectomized rats daily for 3 days and then on alternate days. This produced a highly significant decrease in the mean heart rate when averaged over the days 4 to 7 [ [from 299 to 253 $(\mathrm{p}<0.001)]$, and there was a further decrease in the mean averaged over the days 8 to 11 [from 299 to $233(\mathrm{p}<0.001)]$. After 11 days, the rats were still alive and healthy with the heart rate depressed only $20 \%$ over control. The decrease from 253 to 233 was not statistically significant. Daily doses of 100 or $200 \mu \mathrm{g}$ of reserpine were given respectively to two and three normal rats. The regression equation for the rats receiving $100 \mu \mathrm{g}$ daily is $y=-3.3 x+1.8$, where $y$ is the response and $x$ the time in days after day 1 . The difference of this slope from zero is of borderline statistical significance $(p=0.05)$. The rats receiving the $200-\mu \mathrm{g}$ dose showed a highly significant decline in heart rate with time expressed by the regression equation $y=-8 x+11$. No rats from either of these groups died or appeared ill during the 2 weeks of this study.

The death of the thyroidectomized-adrenodemedullated rats treated with reserpine led to another study using 30 male hooded rats receiving $10 \mu \mathrm{g}$ of reserpine (Table III). A $10-\mu \mathrm{g}$ dose of reserpine is sufficient to deplete heart catecholamines but probably not other peripheral stores or the brain catecholamines (33-35). The rats were treated for 3 weeks as follows: three thyroidectomized rats and three thyroidectomized-adrenodemedullated rats received $10 \mu \mathrm{g}$ of triiodothyronine on alternate days for four injections and daily thereafter; six rats from each group received the same course of triiodothyronine plus $10 \mu \mathrm{g}$ of reserpine in peanut oil intramuscularly for 3 consecutive days and then on alternate days; the remaining rats from each group were divided in half, five receiving $\mathrm{NaCl}$ and reserpine, and five receiving $\mathrm{NaCl}$ and peanut oil. A comparison of the control data before treatment revealed, as in the previous study, no difference in heart rate or metabolic rate owing to adrenodemedullation. The lower dose of reserpine, like the higher one used previously, was successful in preventing the rise in heart rate that followed triiodothyronine. The rise in oxygen consumption after thyroid was again greater in the rats receiving reserpine. Reserpine, $10 \mu \mathrm{g}$, did not kill thyroidectomized-adrenodemedullated rats nor did it lower their BMR. It did, however, lower the heart rate significantly, but not progressively.

The failure of the heart rate to rise after treatment with reserpine and triiodothyronine could be due to a direct effect of reserpine on myocardial oxygen consumption or to an indirect ef-

TABLE III

Effect of triiodothyronine and reserpine on the BMR and heart rate of thyroidectomized or thyroidectomized-adrenodemedullated male hooded-strain rats

\begin{tabular}{|c|c|c|c|c|c|c|c|c|}
\hline \multirow[b]{3}{*}{ Group } & \multirow{3}{*}{$\begin{array}{l}\text { No. of } \\
\text { animals }\end{array}$} & \multirow{2}{*}{\multicolumn{3}{|c|}{ Treatments }} & \multicolumn{2}{|c|}{ Effect on $B M R$} & \multicolumn{2}{|c|}{ Effect on heart rate } \\
\hline & & & & & \multirow{2}{*}{$\begin{array}{c}\text { Mean } \\
\text { control }\end{array}$} & \multirow{2}{*}{$\begin{array}{c}\text { Mean of } \\
\text { days } 4 \text { to } 7 \\
\text { after treat- } \\
\text { ment }\end{array}$} & \multirow{2}{*}{$\begin{array}{c}\text { Mean } \\
\text { control }\end{array}$} & \multirow{2}{*}{$\begin{array}{l}\text { Mean of } \\
\text { days } 4 \text { to } 7 \\
\text { af ter treat- } \\
\text { ment }\end{array}$} \\
\hline & & A.D.* & $T-3 \dagger$ & Reserpine $\neq$ & & & & \\
\hline 1 & 2 & & & & 1.71 & 1.65 & 305 & 312 \\
\hline 2 & 3 & Yes & & & 1.62 & 1.57 & 278 & 287 \\
\hline 3 & 6 & & Yes & Yes & 1.66 & 1.868 & 303 & 332 \\
\hline 4 & 6 & Yes & Yes & Yes & 1.66 & $1.89 \|$ & 289 & 312 \\
\hline $\begin{array}{l}\mathbf{4} \\
5\end{array}$ & 3 & & Yes & & 1.71 & $1.91 \S$ & 298 & $417 \S$ \\
\hline 6 & 3 & Yes & Yes & & 1.78 & 1.938 & 298 & $364 \pi$ \\
\hline 7 & 3 & & & Yes & 1.55 & 1.62 & 296 & 283 \\
\hline 8 & 2 & Yes & & Yes & 1.41 & 1.62 & 309 & $284 \S$ \\
\hline
\end{tabular}

* A.D., adrenodemedullation.

$\dagger \mathrm{T}-3$, triiodothyronine, $10 \mu \mathrm{g}$ per rat every other day for 1 week and then daily for a second week.

$\ddagger 10 \mu \mathrm{g}$ per rat per day for 3 days, then on alternate days.

$\& p<0.05$.

$\| p<0.001$. 
fect through the autonomic nervous system. To test the effect of reserpine on tissue metabolism, oxygen consumption of heart and liver slices was compared in thyroidectomized-adrenodemedullated rats given triiodothyronine with and without reserpine. The results are summarized in Table IV. The stimulation of myocardial oxygen consumption produced by thyroid as measured under in vitro conditions was not affected by reserpine. Reserpine did, however, significantly depress the oxygen consumption of liver slices from triiodothyronine-treated rats. Thus, it appears that the effect of reserpine in preventing the rise of heart rate after triiodothyronine is not due to a depression of myocardial oxygen consumption per se.

To test the possibility that suppression of the heart rate was due to an alteration in the balance between the sympathetic and parasympathetic nervous systems, heart rates were measured before and 1 hour after atropine. In the early studies atropine was administered at $70 \mathrm{mg}$ per $100 \mathrm{~g}$, but in most rats the dose was reduced to $35 \mathrm{mg}$ per $100 \mathrm{~g}$ given subcutaneously. A summary of the data is shown in Table V. The highly significant suppression of heart rate produced by reserpine was completely abolished by atropine, and, in additon, there was a significant increase in the heart rate of the rats treated with only triiodothyronine.

In a final study the effect of guanethidine was investigated. Twelve male albino thyroidectomized-adrenodemedullated rats were divided into three groups. Three rats received guanethidine, $0.5 \mathrm{mg}$ per $100 \mathrm{~g}$, subcutaneously once daily; six received $0.5 \mathrm{mg}$ per $100 \mathrm{~g}$ of guanethidine plus

TABLE IV

Effect of triiodothyronine and reserpine on the $B M R$ and oxygen consumption by liver and heart slices

\begin{tabular}{|c|c|c|c|}
\hline & $\begin{array}{l}\text { Sodium } \\
\text { chloride } \\
\text { Peanut oil }\end{array}$ & $\begin{array}{l}\text { Triiodo- } \\
\text { thyronine } \\
\text { Peanut oil }\end{array}$ & $\begin{array}{l}\text { Triiodo- } \\
\text { thyronine } \\
\text { Reserpine }\end{array}$ \\
\hline No. of animals & 4 & 5 & 5 \\
\hline $\begin{array}{l}\text { BMR, \% change } \\
\text { from control }\end{array}$ & $1.4 \pm 2.0^{*}$ & $32.5 \pm 11.0$ & $43.4 \pm 16.8$ \\
\hline $\begin{array}{l}\mathrm{QO}_{2}, \text { heart slices, } \\
\mu \mathrm{l} / \mathrm{g} \text { wet wt/hr}\end{array}$ & $163 \pm 24$ & $464 \pm 31$ & $489 \pm 77$ \\
\hline $\begin{array}{l}\mathrm{QO}_{2}, \text { liver slices, } \\
\mu l / g \text { wet } w t / h r\end{array}$ & $708 \pm 54$ & $1,554 \pm 112 \dagger$ & $928 \pm 180 \dagger$ \\
\hline
\end{tabular}

TABLE V

Effect of atropine and reserpine on the heart rate of thyroidectomized-adrenodemedullated rats treated with triiodothyronine

\begin{tabular}{|c|c|c|c|}
\hline & \multirow{2}{*}{$\underset{\text { animals }}{\text { No. of }}$} & \multicolumn{2}{|c|}{ Mean heart rate } \\
\hline & & $\begin{array}{c}\text { Before } \\
\text { atropine }\end{array}$ & $\begin{array}{c}\text { After } \\
\text { atropine }\end{array}$ \\
\hline $\begin{array}{l}\text { Reserpine } \\
\text { No reserpine }\end{array}$ & $\begin{array}{l}11 \\
10\end{array}$ & $\begin{array}{l}328 \\
422\end{array}$ & $\begin{array}{l}477 \\
482\end{array}$ \\
\hline
\end{tabular}

$10 \mu \mathrm{g}$ of triiodothyronine daily, and three rats received only triiodothyronine. In the groups receiving triiodothyronine there was a prompt rise in heart rate and BMR that was not affected by guanethidine at $0.5 \mathrm{mg}$ per $100 \mathrm{~g}$ (Figure 5). Of the three rats receiving guanethidine alone, one died within 48 hours, a second showed a drop in heart rate and BMR with death after day 6, and the third showed a drop in BMR (from 133 to 54 ), at which time guanethidine was discontinued; the rat recovered. The experiment was re-
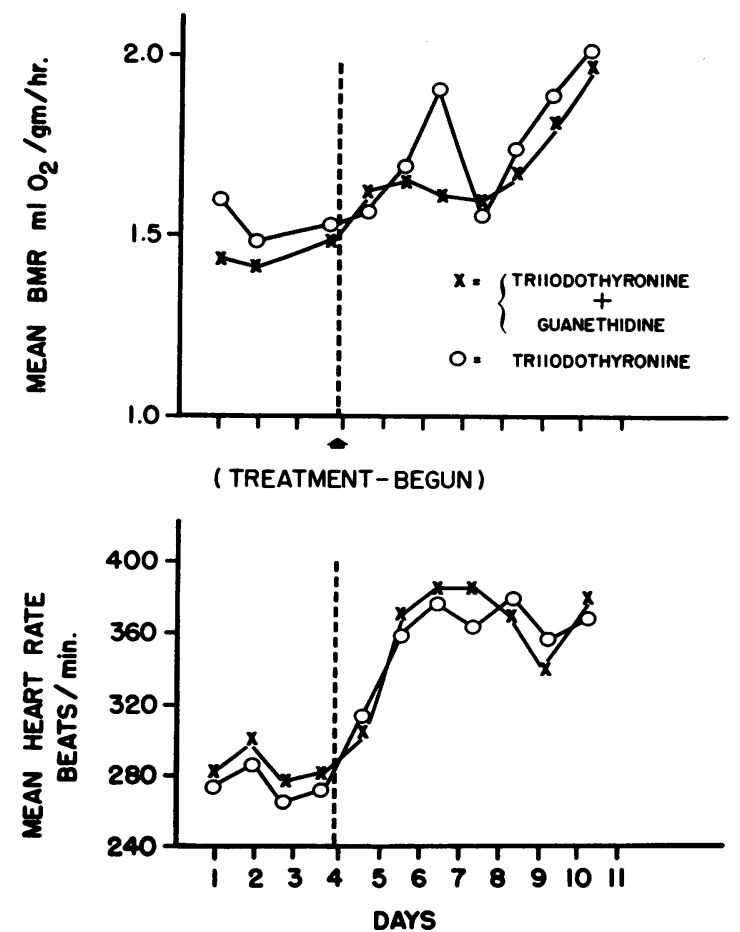

Fig. 5. EFFECT OF TRIIODOTHYRONINE AND GUANETHIDINE ON THE HEART RATE AND METABOLIC RATE OF THYROIDECTOMIZED AND THYROIDECTOMIZED-ADRENODEMEDULLATED RATS. The open circles represent the mean readings from three animals; the crosses represent the mean of readings from six animals. 

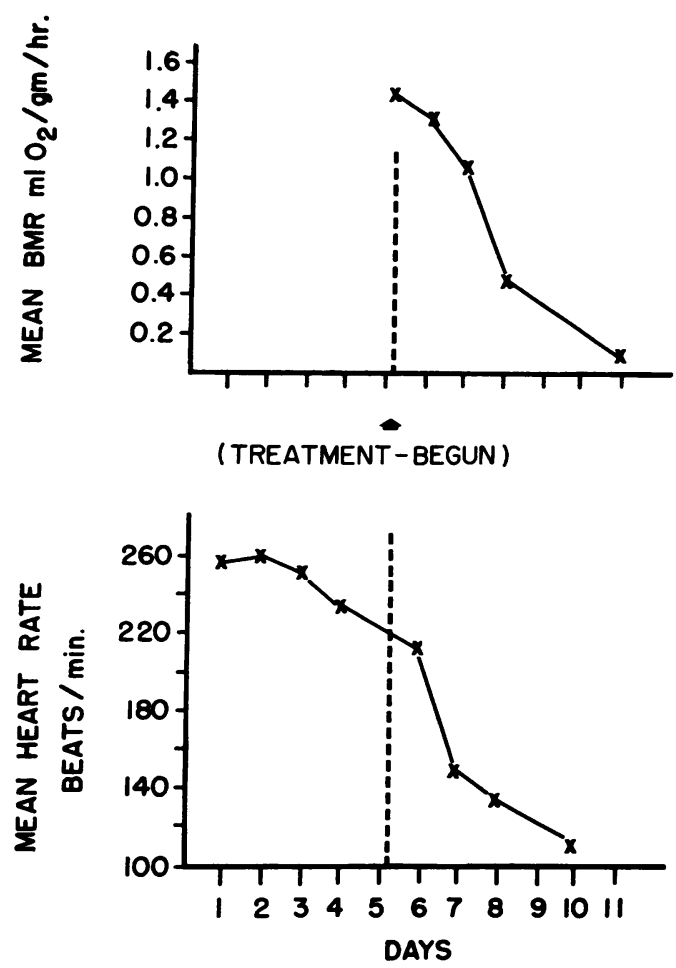

Fig. 6. EFFECT OF GUANETHIDINE ON THE METABOLIC RATE AND HEART RATE OF THREE THYROIDECTOMIZEDADRENODEMEDULLATED RATS.

peated on three rats that had been thyroidectomized and adrenodemedullated more than 10 weeks previously. The response to $0.5 \mathrm{mg}$ per 100 $\mathrm{g}$ of guanethidine on BMR and heart rate of these rats is seen in Figure 6. All rats were dead within 1 week of beginning guanethidine.

\section{Discussion}

The hypothesis tested in this paper was that the metabolic and hemodynamic manifestations of thyroid hormone were mediated at the tissue level through the action of catecholamines. The data suggest that the extent to which catecholamines are responsible for the manifestations of the thyroid hormone depends on the extent to which the functions measured are normally under adrenergic control. In heart rate the adrenergic component predominates, but in the metabolic rate and probably growth rate the extent of sympathetic control is negligible.

Thyroid hormones induce a rise in heart rate. This tachycardia has been shown to involve all rhythmic elements of the heart (36) and is ac- companied by an increased sensitivity to catecholamines $(8,10)$ and a rise in myocardial oxygen consumption (37-39). It can be inhibited by the sympathetic blockade of epidural anesthesia (8), by reserpine $(21,40)$ or guanethidine $(22,23)$, and by complete heart block (41). It thus seems that the tachycardia of the hyperthyroid state is primarily due to adrenergic stimulation.

The increased myocardial sensitivity to catecholamines induced by thyroid hormones and the ability to inhibit the thyroid-induced tachycardia with techniques that interfere with the sympathetic nervous system suggest that this tachycardia is primarily due to adrenergic stimulation. The effect of reserpine on the heart rate of thyroidtreated rats is consistent with this concept. Reserpine in the doses used in these experiments has been shown to deplete the norepinephrine stores in the heart. The lower dose $(10 \mu \mathrm{g}$ given to a $150-\mathrm{g}$ rat) is, however, probably insufficient to deplete brain catecholamines (33-35). Both doses lowered heart rate. Adrenodemedullation had no effect. Triiodothyronine raised the depressed heart rate of reserpine-treated rats to control levels, but did not produce any further rise.

The importance of the autonomic nervous system in controlling the heart rate changes after thyroid is further emphasized by the studies with atropine. An increase in sensitivity to cholinergic agents has been demonstrated in hyperthyroid states $(42,43)$. Further, it is known that reserpine produces a bradycardia that is overcome by atropine. In the current studies atropine caused a significant rise in heart rate in rats treated with thyroid alone. The same dose of atropine given to hyperthyroid rats receiving reserpine caused a heart-rate rise to the same level as hyperthyroid rats. If reserpine is presumed to inhibit sympathetic nerve transmission by depleting myocardial and nerve supplies of catecholamines, then the bradycardia seen would be the result of a relative increase in vagal activity. By blocking the vagus one would expect the heart rate to rise. It is difficult to explain, however, why both groups reached the same heart rate. One possibility is that the heart rate had reached an intrinsic upper limit determined by its metabolic characteristics.

The ability of reserpine to prevent the tachy- 
cardia produced by thyroid led to an investigation in vitro of the myocardial oxygen consumption of these animals. Other evidence has been reported suggesting that alterations in myocardial oxygen consumption play only a minor role in thyroidinduced changes in heart rate (22). As seen in Table IV, the threefold rise in heart slice oxygen consumption after thyroid administration was not altered by reserpine. Thus, under physiological conditions, the rate of oxygen consumption by the heart has little or no effect on heart rate changes induced by thyroid in vivo. A case of complete heart block has been reported in which large doses of thyroid raised the BMR and the atrial rate without altering the ventricular rate (41).

Although the hemodynamic manifestations of thyroid hormones appear to be predominantly under autonomic nervous system control, the effects of thyroid on metabolism are only indirectly under such control. Several studies have shown that thyroid hormones increase the calorigenic action of epinephrine $(6,7,14)$, and some authors have reported that drugs which interfere with sympathetic activity can prevent the rise in oxygen consumption after thyroid $(17-20)$. It has not been possible, however, to demonstrate an effect of reserpine on the increase in oxygen consumption produced by triiodothyronine in the experiments reported here, nor was Schwartz (26) able to show an effect of dibenzyline on the rise in oxygen consumption produced by thyroid. Indeed, the administration of reserpine may have enhanced the effect of triiodothyronine on the BMR (Table I, groups 5 vs. 6 and 8 vs. 9; Table II, groups 3 and 4 vs. 5 and 6 ). Thus, until new evidence is presented, one must conclude that thyroid hormones can raise the metabolic rate independent of the sympathetic nervous system and the catecholamines.

Attempts to show that the sympathetic nervous system has a role in maintaining the BMR in euthyroid animals have also been unsuccessful $(28,44,45)$. If one removes the adrenal medulla and the thyroid, however, it is then possible to depress the hypothyroid BMR and kill rats with either reserpine or guanethidine in doses that have no lethal or BMR-depressing effects in hypothyroid rats with intact adrenal medullas. The basis for this phenomenon is not yet clear. It can be prevented by injections of epinephrine or tri- iodothyronine. Corticoid production, though not measured, is probably not deficient, since other studies have shown that at the time these animals are used ( 6 weeks after adrenodemedullation) the adrenal cortex responds normally to stress (46). It is known from the work of Ring (7) that adrenodemedullation reduces the ability of the rat to increase heat production when exposed to cold. Reserpine has also been shown to reduce the ability of rats to raise their heat production when exposed to lowered ambient temperatures. The careful studies of Adolph and his collaborators (47) have demonstrated a linear relation between body temperature and heart rate or metabolism. Thus, the decrease in heart rate and BMR or reserpine- or guanethidinetreated, thyroidectomized-adrenodemedullated rats may represent a decreased heat production relative to the demands for maintaining body temperature of animals living at room temperature.

The studies on the effect of adrenodemedullation on growth suggest that the catecholamines have a role in the effect of thyroid on growth. These data need to be interpreted with caution. Adrenodemedullation in the rat removes not only the medulla but also the cortex except for the cells lining the capsule. These remaining cells are the source from which the cortex is regenerated. Complete return of normal function, however, requires about 4 weeks. Thus, the observed effect of adrenodemedullation may represent inadequate cortical hormone output during adrenal regeneration.

\section{Summary}

Studies have been carried out to assess the effect of adrenodemedullation and reserpine on the growth rate, metabolic rate, and heart rate of thyroidectomized rats given thyroid. Adrenodemedullation significantly reduced the growth rate, but was without effect on the heart rate or metabolic rate.

The effects of reserpine are complex. It lowered the growth rate slightly of thyroid-treated rats, while raising slightly the growth rate of thyroidectomized rats. Reserpine lowered heart rate of thyroidectomized rats and prevented the tachycardia usually induced by triiodothyronine. This effect on heart rate was abolished by atropine and was not accompanied by any change in the in vitro 
oxygen consumption of myocardial tissue. Reserpine and guanethidine were lethal to thyroidectomized-adrenodemedullated rats but not to rats with intact adrenal medullas. The death of these rats was accompanied by a progressive decline in metabolic rate and heart rate and was prevented by triiodothyronine and epinephrine. These observations are discussed in relation to the thyroid hormones on the control of heart rate and metabolism.

\section{Acknowledgments}

The author expresses his thanks to Sir Charles Harington for providing laboratory facilities and to Dr. R. Pitt-Rivers for her constant encouragement and helpful discussions. The statistical work of Miss V. Mussett and the invaluable technical assistance of Miss $\mathrm{H}$. Charap are gratefully acknowledged.

\section{References}

1. Magnus-Levy, A. Ueber den respiratorischen Gaswechsel unter dem Einfluss der Thyreodea sowie unter verschiedenen pathologische Zustanden. Berl. klin. Wschr. 1895, 32, 650.

2. Harington, C. R., and G. Barger. Chemistry of thyroxine. III. Constitution and synthesis of thyroxine. Biochem. J. 1927, 21, 169.

3. Pitt-Rivers, R., and J. R. Tata. The Thyroid Hormones. New York, Pergamon Press, 1959.

4. Hoch, F. L. Biochemical action of thyroid hormones. Physiol. Rev. 1962, 42, 605.

5. Goetsch, E. Newer methods in the diagnosis of thyroid disorders: pathological and clinical: $\mathrm{B}$. Adrenaline hypersensitiveness in clinical states of hyperthyroidism. N. Y. St. J. Med. 1918, 18, 259.

6. Barker, S. B., J. F. Fazikas, and H. E. Himwich. Metabolic aspects of thyroid-adrenal interrelationship. Amer. J. Physiol. 1936, 115, 415.

7. Ring, G. C. The importance of the thyroid in maintaining an adequate production of heat during exposure to cold. Amer. J. Physiol. 1942, 137, 582.

8. Brewster, W. R., Jr., J. P. Isaacs, P. F. Osgood, and T. L. King. The hemodynamic and metabolic interrelationships in the activity of epinephrine, norepinephrine and the thyroid hormones. Circulation 1956, 13, 1.

9. Sawyer, M. M. E., and M. G. Brown. The effect of thyroidectomy and thyroxine on the response of the denervated heart to injected and secreted adrenine. Amer. J. Physiol. 1935, 110, 620.

10. Rosenblum, H., R. G. Hahn, and S. A. Levine. Epinephrine: its effect on the cardiac mechanism in experimental hyperthyroidism and hypothyroidism. Arch. intern. Med. 1933, 51, 279.

11. Raab, W. Epinephrine tolerance of the heart altered by thyroxine and thiouracil. Chemical assay of epinephrine in the rat heart. J. Pharmacol. exp. Ther. 1944, 82, 330.
12. Schneckloth, R. E., G. S. Kurland, and A. S. Freedberg. Effect of variation in thyroid function on the pressor response to norepinephrine in man. Metabolism 1953, 2, 546.

13. McDonald, C. H., W. L. Shepeard, M. F. Green, and A. F. DeGroat. Response of the hyperthyroid heart to epinephrine. Amer. J. Physiol. 1935, 112, 227.

14. Swanson, H. E. Interrelations between thyroxin and adrenalin in the regulation of oxygen consumption in the albino rat. Endocrinology 1956, 59, 217.

15. Trendelenburg, U. Thyroid and hyperglycaemia produced by adrenaline and noradrenaline. Brit. J. Pharmacol. 1953, 8, 454.

16. Comsa, J. Adrenaline-thyroxin interaction in guinea pigs. Amer. J. Physiol. 1950, 161, 550.

17. Holtkamp, D. E., and A. E. Heming. Effect of concurrent dibenzyline administration on thyroxineinduced and epinephrine-induced increased oxygen consumption (abstract). J. clin. Endocr. 1953, 13, 853.

18. Ramey, E. R., H. Bernstein, and M. S. Goldstein. Effect of sympathetic blocking agents on the increased oxygen consumption following administration of thyroxine. Fed. Proc. 1955, 14, 118.

19. De Felice, E. A., T. C. Smith, and E. H. Dearborn. Effect of reserpine (Serpasi1@) on oxygen consumption of euthyroid, hypothyroid, and hyperthyroid guinea pigs. Proc. Soc. exp. Biol. (N. Y.) 1957, 94, 171.

20. Kuschke, H. J., and H. Gruner. Reserpin als thyroxin-antagonist. Klin. Wschr. 1954, 32, 563.

21. Canary, J. J., M. Schaaf, B. J. Duffy, Jr., and L. H. Kyle. Effects of oral and intramuscular administration of reserpine in thyrotoxicosis. New Engl. J. Med. 1957, 257, 435.

22. Gaffney, T. E., E. Braunwald, and R. L. Kahler. Effects of guanethidine on triiodothyronine induced hyperthyroidism in man. New Engl. J. Med. 1961, 265, 16.

23. Lee, W. Y., D. Bronsky, and S. S. Waldstein. Studies of thyroid and sympathetic nervous system interrelationships. II. Effect of guanethidine on manifestations of hyperthyroidism. J. clin. Endocr. 1962, 22, 879.

24. Surtshin, A., J. K. Cordonnier, and S. Lang. Lack of influence of the sympathetic nervous system on the calorigenic response to thyroxine. Amer. J. Physiol. 1957, 188, 503.

25. Sawyer, H. K., Jr., and H. J. Lipner. Effects of dihydroergotamine on athyroid and thyroxinized rats. Amer. J. Physiol. 1961, 201, 264.

26. Schwartz, N. B. Effect of Dibenzyline on the metabolic actions of epinephrine and thyroxine. Amer. J. Physiol. 1962, 203, 525.

27. Thier, M. D., J. S. Gravenstein, and R. G. Hoffmann. Thyroxin, reserpine, epinephrine and temperature on atrial rate. J. Pharmacol. exp. Ther. 1962, $136,133$. 
28. McIntyre, M. The effects of thyroid feeding on the heart rate in normal dogs and in dogs with completely denervated hearts. Amer. J. Physiol. 1931, 99, 261.

29. Farris, E. J., and J. Q. Griffith, Jr., Eds. The Rat in Laboratory Investigation, 2nd ed. Philadelphia, J. B. Lippincott, 1949.

30. Crout, J. R. Catechol amines in urine in Standard Methods of Clinical Chemistry, D. Seligson, Ed. New York, Academic Press, 1961, vol. 3, p. 62.

31. Maclagan, N. F., and M. M. Sheahan. The measurement of oxygen consumption in small animals by a closed circuit method. J. Endocr. 1950, 6, 456.

32. Deutsch, W. An improvement of Warburg's method for cutting tissue slices for respiratory experiments. J. Physiol. (Lond.) 1936, 87, 56P.

33. Crout, J. R., A. J. Muskus, and U. Trendelenburg. Effect of tyramine on isolated guinea-pig atria in relation to their noradrenaline stores. Brit. J. Pharmacol. 1962, 18, 600.

34. Paasonen, M. K., and O. Krayer. The content of noradrenaline and adrenaline in the rat heart after administration of Rauwolfia alkaloids. Experientia (Basel) 1959, 15, 75.

35. Orlans, F. B. H., K. F. Finger, and B. B. Brodie. Pharmacological consequences of the selective release of peripheral norepinephrine by syrosingopine (SU 3118). J. Pharm. exp. Ther. 1960, 128, 131.

36. Priestley, J. T., J. Markowitz, and F. C. Mann. The tachycardia of experimental hyperthyroidism. Amer. J. Physiol. 1931, 98, 357.

37. Dock, W., and J. K. Lewis. The effect of thyroid feeding on the oxygen consumption of the heart and of other tissues. J. Physiol. (Lond.) 1932, 74, 401.
38. McEachern, D. Direct measurements of the oxygen consumption of isolated beating auricles from normal and thyrotoxic guinea-pigs. Bull. Johns Hopk. Hosp. 1932, 50, 287.

39. Ullrick, W. C., and W. V. Whitehorn. Influence of thyroid hormone on respiration of cardiac tissue. Amer. J. Physiol. 1952, 171, 407.

40. Buchanan, J. W., W. Buchanan, J. Crooks, and G. E. Gale. The use of reserpine in the treatment of thyrotoxicosis. Scot. med. J. 1959, 4, 486.

41. Aub, J. C., and N. S. Stern. The influence of large doses of thyroid extract on the total metabolism and heart in a case of heart-block. Arch. intern. Med. 1918, 21, 130.

42. Wise, B., and H. E. Hoff. The effect of autonomic hormones on the thyrotoxic heart. J. Pharmacol. exp. Ther. 1938, 64, 217.

43. Nahum, L. H., and H. E. Hoff. Auricular fibrillation in hyperthyroid patients. J. Amer. med. Ass. 1935, 105, 254.

44. Cannon, W. B., H. F. Newton, E. M. Bright, V. Menkin, and R. M. Moore. Some aspects of the physiology of animals surviving complete exclusion of the sympathetic nerve impulses. Amer. J. Physiol. 1929, 89, 84.

45. Lee, M. O., and Z. M. Bacq. The failure of sympathetic extirpation in the rat to affect the basal metabolism or the calorigenic action of adrenaline. Amer. J. Physiol. 1933, 103, 637.

46. Yates, F. E., and J. Urquhart. Control of plasma concentrations of adrenocortical hormones. Physiol. Rev. 1962, 42, 359.

47. Adolph, E. F. Oxygen consumptions of hypothermic rats and acclimitization to cold. Amer. J. Physiol. 1950, 161, 359. 